\title{
STEROLS AND FECAL INDICATOR MICROORGANISMS IN SEDIMENTS FROM ADMIRALTY BAY, ANTARCTICA
}

\author{
* César de Castro Martins ${ }^{I}$, Rosalinda Carmela Montone ${ }^{I}$, Rosa Carvalho Gamba ${ }^{2}$ \& Vivian Helena Pellizari ${ }^{2}$ \\ ${ }^{1}$ Instituto Oceanográfico da Universidade de São Paulo \\ Laboratório de Química Orgânica Marinha \\ (Praça do Oceanográfico, 191, 05508-900, São Paulo, SP, Brazil) \\ ${ }^{2}$ Instituto de Ciências Biomédicas da Universidade de São Paulo \\ Laboratório de Microbiologia Ambiental \\ (Avenida Lineu Prestes, 1374, São Paulo, SP, Brazil)
}

\begin{abstract}
A B S T R A C T
Sediments from the proximity of Ferraz station outfall, located in Admiralty Bay, Antarctica, were analyzed for fecal indicator microorganisms and sterols during the austral summer of 1999/2000 in order to assess human sewage input. Concentrations of total sterols and coprostanol ranged from 0.09 to $19.6 \mu \mathrm{g} \cdot \mathrm{g}^{-1}$ and $<0.01$ and $14.0 \mu \mathrm{g} \cdot \mathrm{g}^{-1}$ dry weight $(\mathrm{dw})$, respectively. Our analyses indicated that only sites within to $400 \mathrm{~m}$ of the sewage outfall exhibited a sterol signal characteristic of human sewage input. Low levels of coprostanol and high levels of cholesterol in distant sites could be attributed to natural sources such as marine mammals and planktonic organisms. Fecal indicator microorganisms (E. coli, fecal streptococci and Clostridium perfringens) were non-detectable beyond $50 \mathrm{~m}$ from outfall. Both indicators (sterols and fecal indicator microorganisms) produced consistent data and fecal sterol parameters have sho wn themselves to be efficient in the evaluation of trace amounts of fecal material. This study concluded that sewage contamination is limited to the immediate vicinity of the sewage outfall. In general, the concentration of fecal sterols and microbiological indicators were lower than in other Antarctic areas.
\end{abstract}

\section{RESUMO}

Amostras de sedimento, coletadas nas proximidades da saída de esgoto da Estação Antártica Comandante Ferraz (Brasil), Antártica, foram medidos durante o verão de 1999/2000. As concentrações de esteróis totais e coprostanol variaram entre 0,09 e $19,6 \mu \mathrm{g} \cdot \mathrm{g}^{-1} \mathrm{e}<0,01 \mathrm{e} 14,0 \mu \mathrm{g} \cdot \mathrm{g}^{-1}$ de sedimento seco. Nossas análises mostraram que apenas os pontos localizados até $400 \mathrm{~m}$ desde a saída de esgotos apresentaram contribuições provenientes do esgoto da estação brasileira. Baixos níveis de coprostanol e alta concentração de colesterol em pontos distantes puderam ser atribuídos a fontes naturais, como os mamíferos marinhos e organismos planctônicos. Indicadores microbiológicos (E. coli, streptococci fecais e Clostridium perfringens) não foram detectados até 50 $\mathrm{m}$ desde a saída de esgotos. Ambos indicadores de poluição fecal produziram dados consistentes, embora os esteróis fecais tenham sido mais apropriados para avaliar quantidades traço de material fecal. Este estudo concluiu que a contaminação por esgotos está limitada apenas aos pontos mais próximos da saída de esgoto. Em geral, as concentrações de esteróis fecais e indicadores microbiológicos foram menores do que em outras regiões antárticas e centros urbanos.

Descriptors: Fecal sterols, Coprostanol, Microbial indicators, Clostridium, sediments, Antarctica.

Descritores: Esteróis fecais, Coprostanol, Indicadores microbiológicos, Clostridium, sedimentos, Antártica.

\section{INTRODUCTION}

Discharge and dispersion of near-shore sewage plumes in Antarctica have motivated scientists at research stations to evaluate the conditions of

$\overline{\text { Contr. no. } 865}$ do Inst. oceanogr. da Usp.

Corresponding author: Phone: +551130916570

Fax: +551130916610

E-mail: ccmart@usp.br seawater and surface sediments around human sewage outfalls (Howington et al., 1992; McFeters et al., 1993; Bruni et al., 1997; Delille \& Delille, 2000).

Fecal sterols, such as coprostanol $(5 \beta-$

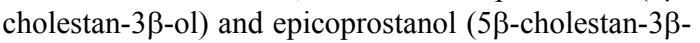
$\mathrm{ol})$, and the stanone $5 \beta$-coprostanone ( $5 \beta$-cholestan-3one) present in human feces, have previously been used as tracers for human waste along coastal areas of industrial and urban centers in temperate regions 
(Venkatesan \& Kaplan, 1990; Grimalti et al., 1990; Jeng \& Han, 1994; Mudge \& Bebianno, 1997; Maldonado et al., 2000) and Antarctic areas (Venkatesan \& Mirsadeghi, 1992; Green \& Nichols, 1995; Edwards et al., 1998; Martins et al., 2002). Coprostanol is persistent in anoxic sediments, easily associates with particulate material and sediments, and has a notable resistance to anaerobic degradation. In combination with cholesterol (cholest-5-en-3 $\beta$-ol) and cholestanol ( $5 \alpha$-cholestan-3 $\beta$-ol), coprostanol is a reliable marker of human sewage pollution (Jeng \& Han, 1994; Nguyen et al., 1995).

Marine mammals and penguins must also be considered as a possible source of coprostanol (seals), epicoprostanol (whales) and cholesterol (seals and penguins) in the Antarctic environment (Venkatesan \& Santiago, 1989). However, the ratios of these sterols: 1) coprostanol/epicoprostanol, 2) the percentage of (coprostanol + epicoprostanol) in total sterols and 3) the percentage of cholesterol in total sterols allow an evaluation of whether the sterols at an impacted site are derived from human sewage or marine mammals (Venkatesan \& Santiago, 1989; Venkatesan \& Kaplan, 1990; Green et al., 1992; Venkatesan \& Mirsadeghi, 1992). The presence of significant amounts of cholesterol in Antarctic sediments suggests the dominance of sterols from phytoplankton, when the biomass of seals and penguins is not large (Venkatesan \& Santiago, 1989).

The survival of human enteric bacteria in the aquatic environment has called attention in view of its public health significance. Fecal microorganisms such as thermotolerant (fecal) coliform bacteria, Escherichia coli, fecal streptococci and Clostridium perfringens have been traditionally used as indicators of sewage pollution (Hill et al., 1996; Leeming \& Nichols, 1996; Lipp et al., 2001).

Enteric microorganisms in the aquatic environment are often reduced as a result of dilution and stress factors (salinity, low temperatures and sunlight). However, some pathogens, such as Salmonella sp., human enteric viruses, Aeromonas $s p$. and $C$. perfringens, survive long enough to contaminate shellfish (Skanavis \& Yanko, 2001). Coliforms have also been shown to accumulate in Lanternula elliptica (benthic bivalves) (Bruni et al., 1997). C. perfringens has previously been shown to be a good microbiological indicator of sewage contamination in sediments (Skanavis \& Yanko, 2001; Davies et al., 1995). These microorganisms form highly resistant endospores that can survive for long periods under extreme conditions such as the low temperatures (Hill et al., 1996) typically found in the Antarctic benthic environments. Colonization of the benthic invertebrates has been confirmed by the presence of increased numbers of $C$. perfringens in several organisms such as the tunicates, sea urchins, starfish and clams from a human sewage impacted site in Antarctica, relative to those from non-impacted sites (Edwards et al., 1998). These findings collectively suggest these allochthonous bacteria persist in sediments, and at the lower levels of the Antarctic food web.

The aims of this study were to analyze sterols and fecal indicator microorganisms in sediments from the vicinity of the sewage outfall of the Brazilian Antarctic Research station and to assess the degree of human sewage input. Data from 1997/98 (Martins et al., 2002) and 1999/2000 (present study) were compared to evaluate the maintenance of the treatment of sewage during these two seasons.

Admiralty Bay is located in the southwestern part of King George Island, South Shetland Islands. There are three research stations in this area: the "Comandante Ferraz" Brazilian Research Station (EACF), the "Henryk Arctowski" Polish Research Station, on the western side of the bay, near Thomas Point and the "Machu Picchu" Peruvian Research Station located near Crepin Point (Fig. 1). The majority of sampling sites were located close to the Brazilian station. This station was established in the summer of 1984, and is a medium size research station with a population of 50 people during the summer, having a sewage system to treat the raw effluent before disposal. All human waste and wastewater from this station receives intermediate primary and secondary treatment before being discharged through a short pipe (10 meters) into the sea. The sewage treatment plant has been in operation since the austral summer of 1995/96 and is designed to serve a population of 50 .

\section{Materials And Methods}

Sediment samples were collected from several points around the Brazilian station in Admiralty Bay (Fig. 1 and Table 1) during the austral summer of 1999/00 with the use of a modified steel Petersen sampler. Sites A, B and C included multiple sampling locations at increasing distances from the coast along transects (Table 1). Approximately $200 \mathrm{~g}$ of surface sediment (the first $3 \mathrm{~cm}$ ) were wrapped in aluminum foil, dried at $50^{\circ} \mathrm{C}$ for three days, homogenized in a mortar with pestle and stored in glass bottles. These samples were analyzed for coprostanol (cop), epicoprostanol (e-cop), cholesterol (chol-e), cholestanol (chol-a) and stanone $5 \beta$ coprostanone (5ß-cop).

The sample processing procedure was based on a method described by Kawakami \& Montone (2002). Briefly, exactly $25.00 \mathrm{~g}$ of sediments from each site was extracted using a Soxhlet system for 8 hours with $70 \mathrm{~mL}$ ethanol. The surrogate, $5 \alpha$ - 
cholestane $(0.35 \mu \mathrm{g})$, was added before each extraction. The ethanol extract was reduced to $\sim 2 \mathrm{~mL}$ by roto-evaporation. The concentrated ethanol extract was purified in a chromatographic column using $2.0 \mathrm{~g}$ of $5 \%$ deactivated alumina, then eluted with $15 \mathrm{~mL}$ of ethanol. The eluents were evaporated to dryness and derivatized to form trimethylsilyl (TMS) ethers using BSTFA (bis(trimethylsilyl)-trifluoroacetamide) with 1 $\mathrm{v} / \mathrm{v}$ trimethylchlorosilane (TMCS) for 90 minutes at $65^{\circ} \mathrm{C}$. Regular analyses for intercomparison exercises as described by the International Atomic Energy Agency (MEL/IAEA) for sterols were performed periodically. Procedural blanks showed a few contaminants that did not interfere with the analyses of target compounds. Recoveries of sterols ranged from
$70-120 \%$. The TMS ethers of sterols were quantified using an HP 5890A Series II gas chromatograph, fitted with a $5 \%$ methyl-phenyl silicone HP Ultra 2 capillary column $(25 \mathrm{~m}, 0.32 \mathrm{~mm}$ ID and $0.17 \mu \mathrm{m}$ film thickness) and flame ionization detector (FID).

The identification of sterols was confirmed by analysis in an HP 5890 series II gas chromatograph coupled with a Mass Spectrometer VG Mass Lab Fisons Model Trio 1000 (GC-MS). The main mass fragments $(\mathrm{m} / \mathrm{z})$ used to identify sterols were $217(5 \alpha-$ cholestane), 215 (coprostanol, epicoprostanol and cholestanol), 129 (cholesterol) and $231 \quad(5 \beta-$ coprostanone).

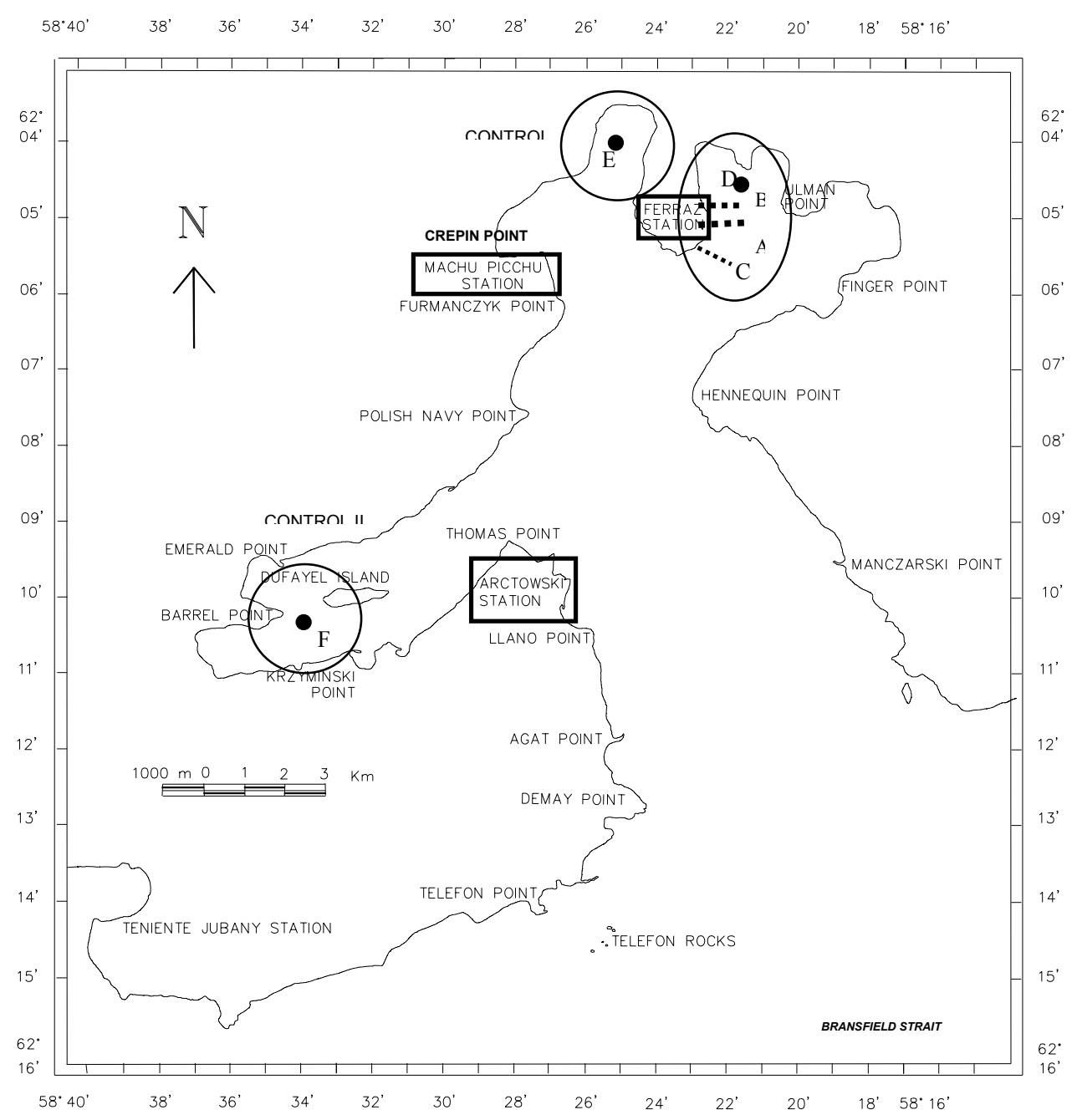

Fig. 1. Sampling stations at Admiralty Bay, King George Island, Antarctica. See Table 1 for station descriptions. 
Table 1. Sediment sampling stations and grain-size in Admiralty Bay, Antarctica.

\begin{tabular}{|c|c|c|c|c|}
\hline Sampling locations & $\begin{array}{c}\text { Sample location } \\
\text { designations }\end{array}$ & $\begin{array}{c}\text { Distance }(\mathrm{Km}) \text { and } \\
\text { direction from } \\
\text { sewage outfall }\end{array}$ & Percentage of silt+clay & $\begin{array}{l}\text { Visual description of } \\
\text { grain-size in sediment }\end{array}$ \\
\hline Ferraz 0 (sewage outfall) & $\mathbf{A}_{1}$ & 0 & 0.02 & gravel \\
\hline Ferraz 10 & $\mathbf{A}_{2}$ & 0.01 & 0.20 & gravel \\
\hline Ferraz 20 & $\mathbf{A}_{3}$ & 0.02 & 12.2 & medium sand \\
\hline Ferraz 50 & $\mathbf{A}_{4}$ & 0.05 & 84.0 & mud \\
\hline Ferraz 100 & $\mathbf{A}_{5}$ & 0.10 & 81.2 & mud \\
\hline Ferraz 200 & $\mathbf{A}_{6}$ & 0.20 & 86.5 & mud \\
\hline Ferraz 400 & $\mathbf{A}_{7}$ & 0.40 & 85.9 & mud \\
\hline Whale 10 & $\mathbf{B}_{1}$ & $0.4(\mathrm{~N})$ & n.a & gravel \\
\hline Whale 20 & $\mathbf{B}_{2}$ & $0.4(\mathrm{~N})$ & n.a & gravel \\
\hline Whale 100 & $\mathbf{B}_{3}$ & $0.5(\mathrm{~N})$ & 13.6 & gravel / mud \\
\hline Whale 200 & $\mathbf{B}_{4}$ & $0.6(\mathrm{~N})$ & 78.4 & mud \\
\hline Refuge-1 10 & $\mathrm{C}_{1}$ & $0.5(\mathrm{~S})$ & n.a & gravel / sand \\
\hline Refuge-1 20 & $\mathrm{C}_{2}$ & $0.5(\mathrm{~S})$ & n.a & coarse sand \\
\hline Refuge-1 50 & $\mathrm{C}_{3}$ & $0.5(\mathrm{~S})$ & n.a & fine sand \\
\hline Refuge-1 100 & $\mathrm{C}_{4}$ & $0.6(\mathrm{~S})$ & 23.7 & gravel / mud \\
\hline Refuge-1 200 & $\mathrm{C}_{5}$ & $0.7(\mathrm{~S})$ & 38.4 & mud \\
\hline Stenhouse Point & D & $0.7(\mathrm{~N})$ & 80.7 & mud \\
\hline Mackelar Glacier (control I) & $\mathbf{E}$ & 5.5 & 51.0 & gravel / mud \\
\hline Barrel Point (control II) & $\mathbf{F}$ & 15.0 & 65.1 & mud \\
\hline
\end{tabular}

n.a: not analyzed; $(\mathrm{N})$ : north; (S): south.

The grain sizes of the sediment samples collected in Admiralty Bay were determined with a Malvern laser sedimentometer, model Mastersizer 2000 , with an analysis capacity of particle sizes ranging from 0.02 to $2000 \mu \mathrm{m}$. The results are presented in Table 1 . The $\%$ (silt + clay) corresponded to the sum of particle sizes of less than $62 \mu \mathrm{m}$, in all the sediment samples analyzed.

For microbiological analysis, the Most Probable Number (MPN) method was used to estimate abundances of total coliforms, Escherichia coli, fecal streptococci and C. perfringens (APHA, 1995). A sample of sediment $(10 \mathrm{~g})$ from each sample was weighed asceptically and serial dilutions (10-fold) were prepared using phosphate buffered water $(1.25$ $\mathrm{mL}$ stock phosphate buffer and $5.0 \mathrm{~mL}$ magnesium chloride solution to $1 \mathrm{~L}$ water, $\mathrm{pH}$ 7.5). A second sediment sample was weighed and dried at $100^{\circ} \mathrm{C}$ to determine dry weight. The MPN method used three dilution series with five tubes at each dilution. Dilutions were inoculated in different culture media according to the target microbial indicator. The following media were used: Colilert (Idexx Laboratories, Inc., Westbrook, USA) for total coliforms (TC) and E. coli (EC); Azide Dextrose Broth (Difco) and Pfizer selective enterococci Agar (Difco) for fecal streptococci (FS) and Differential Reinforced Clostridium Medium (DRCM) (Oxoid) and purple milk (Difco) for detection of $C$. perfringens (CP) under anaerobic conditions as described by Freame \& Fitzpatrick (1972).

The number of positive results from each dilution series were recorded and converted to MPN using a standard reference table (APHA, 1995). The 
95 percent confidence intervals for each MPN value were also obtained. Final results for all indicators were reported as MPN per 100g of dry sediment.

\section{RESUlTS AND Discussion}

\section{Fecal Sterols}

The highest concentration $\left(19.6 \mu \mathrm{g} \cdot \mathrm{g}^{-1}\right)$ of total sterols in the sediments was found at $A_{1}$, at the sewage outfall (Table 2). The lowest concentrations were found in sediments the visual description of which indicated the predominance of coarse fractions $\left(\mathrm{B}_{1}, \mathrm{~B}_{2}, \mathrm{C}_{1}\right.$ and $\mathrm{C}_{2}-$ Table 1$)$. For sites where the percentage of silt+clay was higher than $50 \%$, the lowest sterol concentration occurred at the most distant sample location (site F), approximately $15 \mathrm{Km}$ from the Ferraz Station.

Coprostanol, epicoprostanol and the stanone $5 \beta$-coprostanone, indicators of sewage pollution, were detected at high levels only in the samples collected at the sewer outfall. Their concentrations there were 14.0 $\mu \mathrm{g} . \mathrm{g}^{-1}, 0.62 \mu \mathrm{g} . \mathrm{g}^{-1}$ and $4.09 \mu \mathrm{g} . \mathrm{g}^{-1}$, respectively. At the other sites, the highest concentrations of these three compounds occurred along the sewage outfall transect (sites $\mathrm{A}_{2} \rightarrow \mathrm{A}_{7}$ ), with the following levels: (0.13 $0.17) \mu \mathrm{g} . \mathrm{g}^{-1}$ (cop), $(0.04-0.06) \mu \mathrm{g} . \mathrm{g}^{-1}$ (e-cop) and $(0.02-0.38) \mu \mathrm{g} \cdot \mathrm{g}^{-1}(5 \beta-\mathrm{cop})$, and sites with the (silt+clay) ratio $>50 \%\left(\mathrm{~B}_{4}, \mathrm{D}, \mathrm{E}\right.$ and $\left.\mathrm{F}\right)$, except for site $\mathrm{C}_{4}(23.7 \%)$.

Cholesterol was the dominant sterol in all samples, except at the sewage outfall, where coprostanol was found in larger quantities. The highest values of cholesterol were detected at the sites where the (silt+clay) ratio $>50 \%$. The lowest levels of cholesterol were found in sediments, which were largely composed of gravel $\left(\mathrm{B}_{1}, \mathrm{~B}_{2}, \mathrm{C}_{1}\right.$ and $\left.\mathrm{C}_{2}\right)$. The grain-size of the sediments found at the sites near the sewage outfall was not generally associated with the accumulation of sterols; however, the proximity of the outfall was linked with high concentrations of sterols.

The occurrence of cholesterol at high concentrations together with epicoprostanol, coprostanol and 5 $\beta$-coprostanone in the Antarctic shoreline sediments may be attributed to the feces of marine mammals, such as whales and seals, and penguins (Green \& Nichols, 1995). At the sites along the sewer outfall transect (sites A), cholesterol from human feces may be considered coincident with the Antarctic animal contribution (Venkatesan \& Santiago, 1989). At the sites further from the coast and sewage outfall (such as D and E), the cholesterol may be attributed to algae and phytoplankton (Green \& Nichols, 1995).

To evaluate the anthropogenic contribution based on the fecal sterols in Antarctic sediments, parameters such as the ratios of specific sterols have been used to separate human sewage traces from those of marine mammals. The percentage of cholesterol in total sterols increases with increasing distance from the outfall (Table 2). Sites near the sewage discharge (sites A) receive large amounts of coprostanols (coprostanol + epicoprostanol), thus contributing to a decrease in the percentage of cholesterol in the total sterols. Conversely, sites far from $\mathrm{A}_{1}$ (the outfall) receive more cholesterol from marine mammals. So the percentage of cholesterol is useful in distinguishing possible sources of sterols.

Considering coprostanols are derived from human feces at the sites near outfall, the percentage of coprostanols in total sterols (Table 2, Fig. 2) indicates the degree of human sewage contamination in Admiralty Bay, especially at locations along the sewage outfall transect (sites $A_{1} \rightarrow A_{7}$ ) which are within 0 - 400 meters of the outfall $\left(A_{1}\right)$. Sewage traces decrease in the following order: $\mathrm{A}_{1}>\mathrm{A}_{2}>\mathrm{A}_{6}>$ $A_{7}>A_{4}>A_{5}>A_{3}$ (Fig. 2). Stations $E$ and $F$ (control sites) also exhibit relatively high coprostanols percentages. However, they are much farther $(5,500$ and 15,000 meters) from $A_{1}$ and input at these sites derives primarily from marine mammals.

To estimate the human sewage traces $v s$ the marine mammal contribution, we used the coprostanol/epicoprostanol ratio proposed by Venkatesan \& Santiago (1989).

Table 2 shows a decrease in the coprostanol/epicoprostanol ratio (cop/e-cop) with distance from the outfall. The sites located near the outfall (stations $\mathrm{A}_{1} \rightarrow \mathrm{A}_{7}$ ) presented values of cop/ecop $>2.60$. Only site $A_{1}$ (outfall) presented high fecal sterol content and cop/e-cop ratio, probably because of the high sewage input. At the other sites on this transect, coprostanol and epicoprostanol were detected, but at much lower concentrations than at site $A_{1}$, indicating a dispersion of sewage with increasing distance from the outfall.

The remaining locations, including sites where epicoprostanol was not detected, may be classified as deriving their sterol contributions largely from marine mammals. This was confirmed by the high percentage of cholesterol in total sterols and the lower values of the cop/e-cop ratio (Table 2).

According to Venkatesan \& Santiago (1989), a plot based on cop/e-cop ratio vs the percentage of cholesterol in total sterols made it possible to distinguish the high, medium or low sewage inputs from the Ferraz station outfall from the natural contributions.

A value of 2.60 for the cop/e-cop ratio has been arbitrarily proposed in this report as the limit indicating significant sewage contribution in Admiralty Bay. This figure was based on the sites' distribution on this chart and their distance from the sewage outfall. 
Table 2. Sterol contents in the sediment samples from Admiralty Bay, Antarctica.

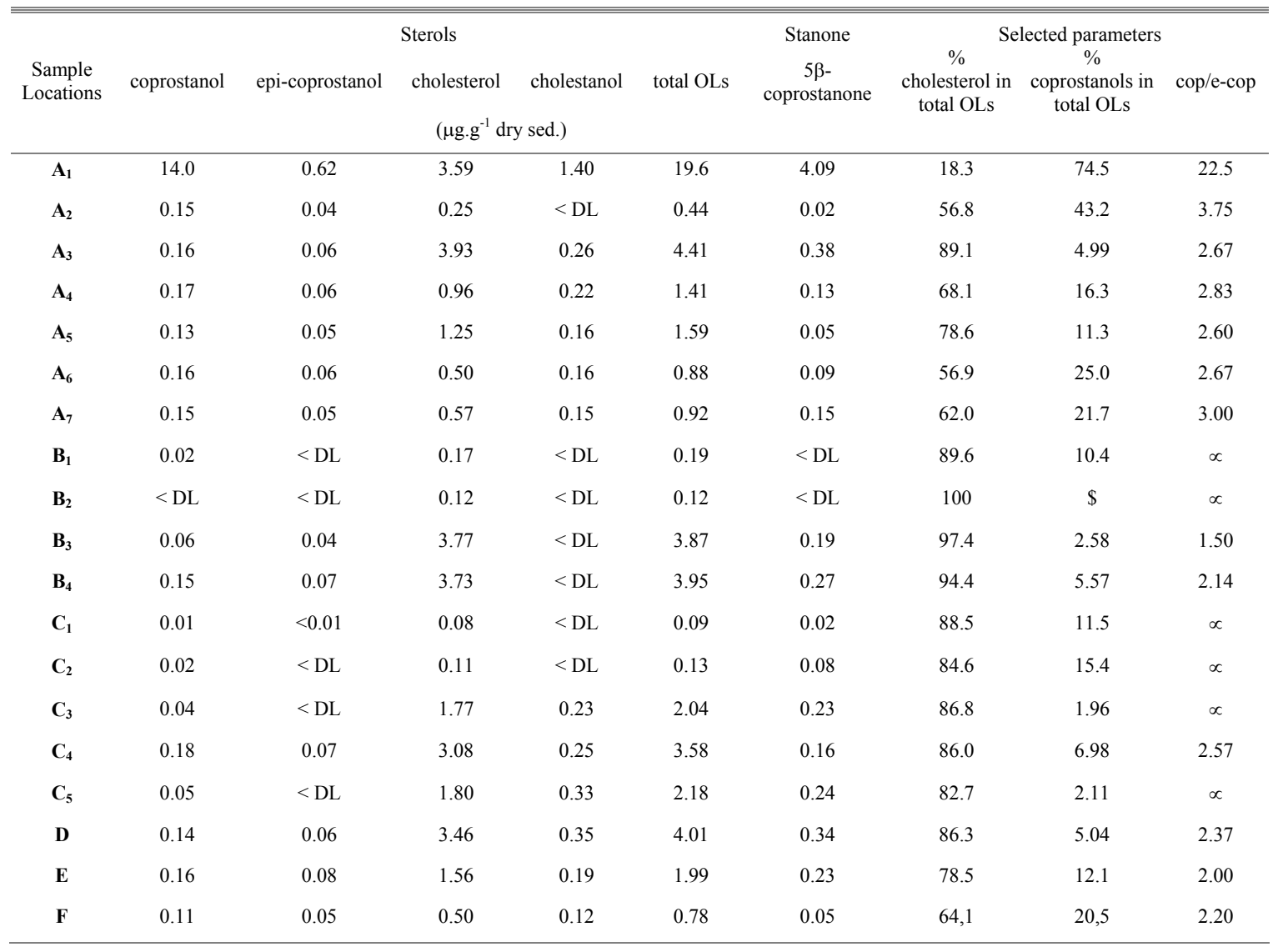

*: not analyzed; < DL: below detection limit (sterols: DL $=0.010 \mu \mathrm{g} . \mathrm{g}^{-1}$ dry sed.); \$: (cop+e-cop) $<$ DL; $\propto$ : e-cop below detection limit.

The plotting of cop/e-cop $v s$ the percentage of cholesterol shows two distinct groups (Fig. 3): a) cop/e-cop $\geq 2.60$ and the percentage of cholesterol $\leq 70 \%$ - (sites along sewage outfall transect) and b) cop/e-cop $<2.60$ or cop/e-cop $=\propto$ (e.g. e-cop below detection limit) and the percentage of cholesterol $>70 \%-($ sites B, C, D and E). For the first group, the value of cop/e-cop ratio, the absolute amount of coprostanol and the percentage of cholesterol $\leq 70 \%$ show that the sewage input was higher than the contribution of Antarctic animals indicating that the signs of human sewage could be detected further than $400 \mathrm{~m}\left(\mathrm{~A}_{7}\right)$ from the sewage outfall. High levels of coprostanol and epicoprostanol decrease the relative proportion of cholesterol in the total sterols. Sites $\mathrm{A}_{3}$ and $\mathrm{A}_{5}$ showed the percentage of cholesterol $>70 \%$; however, the absolute levels of fecal sterols, the distance from the source and cop/e-cop ratio are sufficient to indicate the sources of fecal sterols. The sites on this transect can be classified as moderately $\rightarrow$ slightly or highly (only $A_{1}$ ) sewage impacted areas.

In the second group, the sterol contribution from marine mammals is more significant than the sewage input. All the sites in this group are more than 400 meters from the outfall. Epicoprostanol was detected, implying input from whales and seals. The high cholesterol percentages indicate a large contribution from penguins and seals.

Site F (control II) presented cop/e-cop $<2.60$ and a percentage of cholesterol near $70 \%(64.1 \%)$. It may be classified as receiving a significant contribution from marine mammals, as described above. 


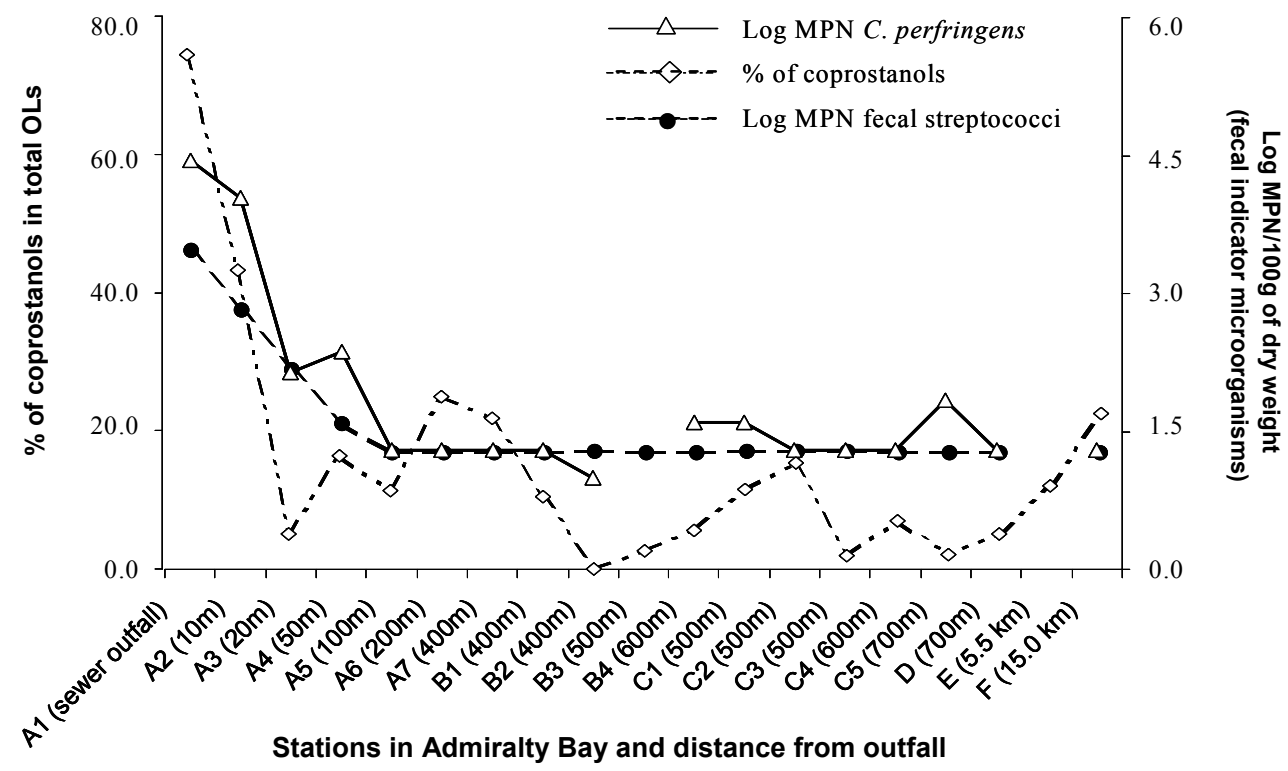

Fig. 2. Plots of parameters involving fecal sterols (coprostanols in total sterols (total OLs)) and fecal indicator microorganisms ( $\log$ (MPN of Clostridium perfringens / 100g dry weight) and $\log (\mathrm{MPN}$ of fecal streptococci / $100 \mathrm{~g}$ dry weight)), for stations in Admiralty Bay.

Notes: Site E not analyzed for fecal streptococci and Clostridium perfringens; Site $\mathrm{B}_{3}$ not analyzed for C. perfringens; when fecal indicator microorganisms were below the detection limit, the detection limit value was used.

Coprostanol was lower than $0.19 \mu \mathrm{g} . \mathrm{g}^{-1}$ at all the sites other than $A_{1}$. Such a level is low as compared to those of sites near density-populated centers, e.g: the Venice lagoon, Italy $\left(>5.00 \mu \mathrm{g} . \mathrm{g}^{-1}\right)$ (Sherwin et al., 1993), the Tan-Shui estuary, Taiwan (33.3 $\mu \mathrm{g} . \mathrm{g}^{-1}, 2 \mathrm{~km}$ from outfall) (Jeng \& Han, 1994), the San Pedro Shelf, U.S.A ( $>1.00 \mu \mathrm{g} . \mathrm{g}^{-1}$ in stations near outfall) (Maldonado et al., 2000). Nichols \& Leeming (1991) showed that concentrations of coprostanol in heavily contaminated sediment might exceed $9 \mu \mathrm{g} \cdot \mathrm{g}^{-1}$.

Table 3 presents data from recent studies on fecal sterols in the Antarctic environment. Coprostanol data from the Ferraz Station sewage outfall lie between the values reported for samples at two different periods from the Davis Station (Green et al., 1992; Green \& Nichols, 1995). All human waste and wastewater from the Davis Station receives primary and secondary treatment before discharge through an outfall pipe into the sea close to the shoreline. The optimum population size served by the installation is about 60 people; however, during the austral summer the population may reach 100 (Green
\& Nichols, 1995). McMurdo Station has a population of between 800 and 1,000 people during summer, and only primary sewage treatment by a macerator was in effect at the time of the study (Edwards et al., 1998). The fecal sterol values from these three stations seem to be commensurate with their type of sewage treatment and the population capacity during the active season.

Comparing these present data with previous results for Admiralty Bay (Martins et al., 2002), total sterol and coprostanol concentrations are similar, showing a constant input of effluent together with the maintenance of the quality of sewage treatment at the Ferraz Station.

Fecal Indicator Microorganisms

Fecal streptococci were found in abundances between $<20$ and $>1.6 \times 10^{5} \mathrm{MPN} / 100 \mathrm{~g}$ dry weight (Table 4). The maximum abundances were found only up to $20 \mathrm{~m}$ from the outfall, at sites $A_{1}, A_{2}$ and $A_{3}$. For the other sites, the number of fecal streptococci varied between $<20$ and $70 \mathrm{MPN} / 100 \mathrm{~g}$ dry weight, close to the detection limit of the method 
(20 MPN/100g dry weight). Bruni et al. (1997) found fecal streptococci bacteria at sites near a small colony of Weddell seals (Leptonychotes weddelli). The usual presence of these species of seals in Admiralty Bay may contribute to the fecal streptococci found in sites remote from the station.

C. perfringens counts ranged from $<20$ to 28 $\mathrm{x} 10^{3} \mathrm{MPN} / 100 \mathrm{~g}$ of dry weight. These microorganisms were found as far as $100 \mathrm{~m}$ from the outfall, though levels decreased at a distance of $50 \mathrm{~m}\left(\right.$ sites $\left.\mathrm{A}_{1} \rightarrow \mathrm{A}_{4}\right)$, with maximum levels at the sewage outfall. The small number of $C$. perfringens found at sites far from the Ferraz Station (sites $\mathrm{B}_{4}, \mathrm{C}_{1}$ and $\mathrm{C}_{5}$ ) may be a result of sediment transport or of the deposition of fecal material by marine birds (Hill et al., 1996).

E. coli were detected in high abundances at sites $\mathrm{A}_{1}$ and $\mathrm{A}_{2}\left(>1.6 \times 10^{5} \mathrm{MNP} / 100 \mathrm{~g}\right.$ sed.). Total coliforms varied between $<20$ and $>1.6 \times 10^{5}$ $\mathrm{MNP} / 100 \mathrm{~g}$ dry weight, the maximum values being found at sites $A_{1}$ and $A_{2}$, similar to those measured for fecal streptococci, $C$. perfringens and E. coli. An unexpectedly high abundance of total coliforms was found at sites $\mathrm{C}_{1}$ and $\mathrm{C}_{2}\left(>1.6 \times 10^{5}\right.$ and $1.1 \times 10^{3}$ $\mathrm{MNP} / 100 \mathrm{~g}$ dry weight), $500 \mathrm{~m}$ from the outfall. Delille \& Delille (2000) reported that coliform bacteria have been detected at Adelie penguin rookeries. These species of penguins are present in Admiralty Bay and around Ferraz Station.
A rapid decline of fecal bacteria abundances was detected near the sewage outfall. Several factors have been proposed as responsible for the reduction in the survival of fecal indicator microorganisms in marine environments. These factors include solar radiation, temperature, salinity, predation and parasitism and low nutrient concentrations (Davies et al., 1995, Muela et al., 2000, Noble et al., 2004). In Antarctica, the effect of solar radiation on enteric bacteria has been found to be of particular importance, mainly during summer when the intensity of daily solar radiation is are high due to the absence of sea ice, which reduces UV transmission through seawater. Hughes (2003) reported an influence of seasonal environmental variables, such as radiation, on the distribution of presumptive fecal coliforms at Rothera Point, on the Antarctic Peninsula. In summer, although that station's population was large (140 people), presumptive fecal coliform concentrations were low, probably due to the damaging effects of solar radiation. By April, the intensity of radiation had fallen by $95 \%$ and the fecal coliform concentrations increased up to $10^{3}$-fold. Previous experiments in the Antarctic aquatic environment have shown that the larger part of cellular damage caused by solar radiation occurs in the top 10 $\mathrm{m}$ of the water column (Karentz et al., 1990).

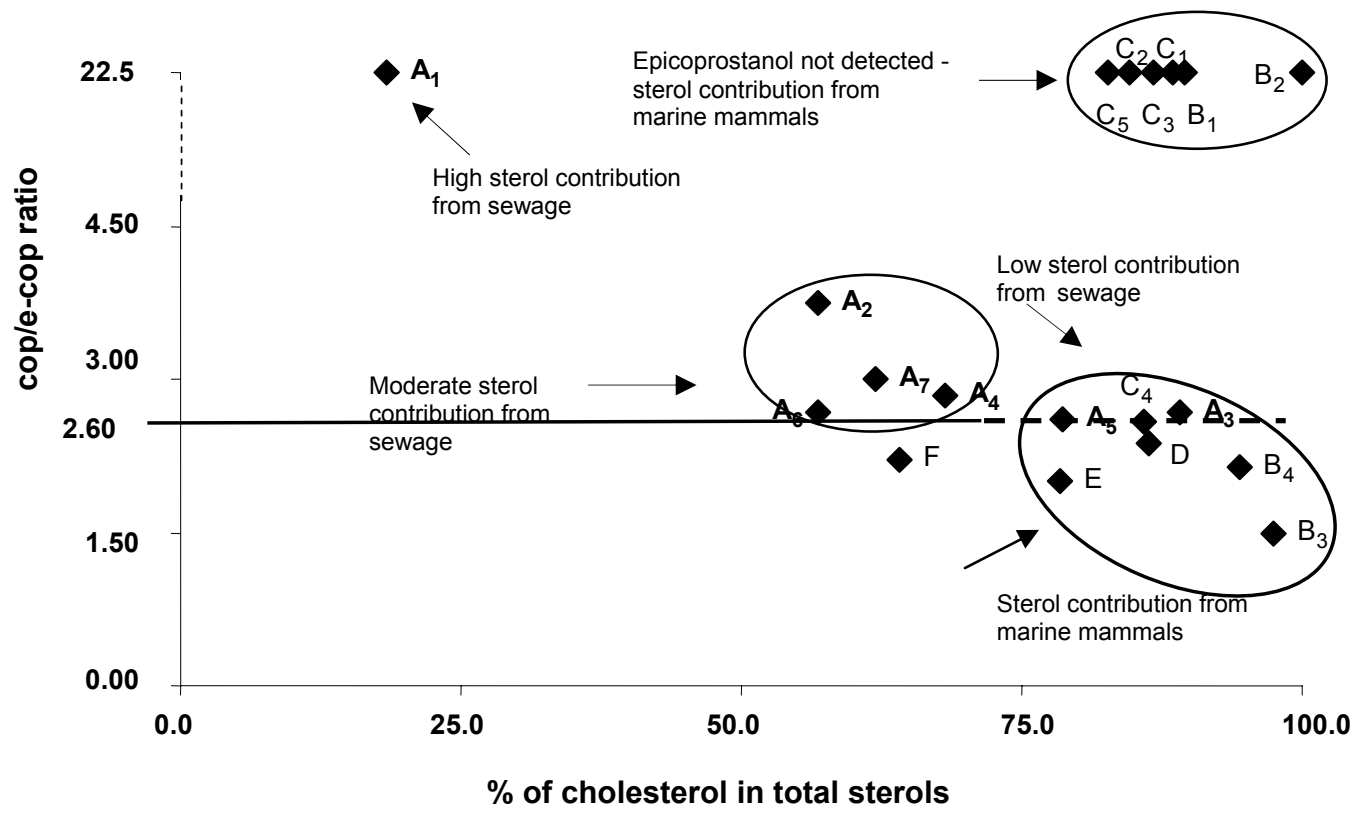

Fig. 3. Coprostanol/epicoprostanol (cop/e-cop) $v s \%$ of cholesterol in total sterols. A value of 2.60 for the cop/e-cop ratio has been arbitrarily proposed as the limit indicating significant sewage contribution in Admiralty Bay. 
Table 3. Relevant sterol parameters for sediments from different Antarctic study areas.

\begin{tabular}{|c|c|c|c|c|c|}
\hline $\begin{array}{l}\text { Sample location } \\
\text { and reference }\end{array}$ & References & $\begin{array}{c}\text { total sterols } \\
\left(\mu \mathrm{g} \cdot \mathrm{g}^{-1}\right)\end{array}$ & $\begin{array}{c}\text { coprostanol } \\
\left(\mu \mathrm{g} \cdot \mathrm{g}^{-1}\right)\end{array}$ & $\begin{array}{c}\text { cop }+ \text { e-cop } \\
\left(\mu g . g^{-1}\right)\end{array}$ & cop/e-cop \\
\hline $\begin{array}{c}\text { Davis Station } \\
\text { (Australia) }\end{array}$ & Green et al., 1992 & $\begin{array}{c}0.46-119 \\
21.8 *\end{array}$ & $\operatorname{tr}-13.2 *$ & n.r & n.r \\
\hline $\begin{array}{l}\text { McMurdo Station } \\
\text { (U.S.A) }\end{array}$ & $\begin{array}{c}\text { Venkatesan \& Mirsadeghi, } \\
1992\end{array}$ & $18-1600$ & $\operatorname{tr}-1500^{*}$ & $\operatorname{tr}-1,500 *$ & $38-\propto$ \\
\hline Davis Station & Green \& Nichols, 1995 & $\begin{array}{l}8.53 \$ \\
20.8 *\end{array}$ & $\begin{array}{c}0.07-1.28 \\
0.25 *\end{array}$ & $0.21-1.32$ & $\begin{array}{l}3.33-4.00 \\
6.67-20.0\end{array}$ \\
\hline $\begin{array}{c}\text { Ferraz Station } \\
\text { (Brazil) } \\
(97 / 98)\end{array}$ & Martins et al., 2002 & $0.21-10.4 *$ & $0.03-6.14 *$ & $0.07-6.43 *$ & $\begin{array}{c}0.59-\propto \\
21.6 *\end{array}$ \\
\hline $\begin{array}{c}\text { Ferraz Station } \\
\qquad(99 / 00)\end{array}$ & present report & $0.09-19.6 *$ & $<0.01-14.0 *$ & $<0.01-14.6 *$ & $\begin{array}{l}1.50-\propto \\
22.5 *\end{array}$ \\
\hline
\end{tabular}

n.d: not detected, n.r: not reported, *: sewage outfall, \$: maximum value, tr: trace amounts, $\alpha$ : e-cop below L.D.

Table 4. Bacterial indicator abundance in sediment samples from Admiralty Bay, Antarctica.

\begin{tabular}{|c|c|c|c|c|c|c|c|c|c|c|c|c|}
\hline \multirow{3}{*}{$\begin{array}{l}\text { Sample } \\
\text { Locations }\end{array}$} & \multicolumn{12}{|c|}{ Fecal microrganisms (MPN/100g dry sed.) } \\
\hline & \multirow{2}{*}{ FS } & \multicolumn{2}{|c|}{$\begin{array}{c}95 \% \text { Confidence } \\
\text { Limits }\end{array}$} & \multirow[t]{2}{*}{$\mathrm{CP}$} & \multicolumn{2}{|c|}{$\begin{array}{c}95 \% \text { Confidence } \\
\text { Limits } \\
\end{array}$} & \multirow{2}{*}{ TC } & \multicolumn{2}{|c|}{$\begin{array}{c}95 \% \text { Confidence } \\
\text { Limits }\end{array}$} & \multirow{2}{*}{$\mathrm{EC}$} & \multicolumn{2}{|c|}{$\begin{array}{c}95 \% \text { Confidence } \\
\text { Limits } \\
\end{array}$} \\
\hline & & Lower & Upper & & Lower & Upper & & Lower & Upper & & Lower & Upper \\
\hline $\mathbf{A}_{1}$ & $>1.6 \times 10^{5}$ & - & - & $2.8 \times 10^{4}$ & $1.2 \times 10^{4}$ & $6.9 \times 10^{4}$ & $>1.6 \times 10^{5}$ & - & - & $>1.6 \times 10^{5}$ & - & - \\
\hline $\mathbf{A}_{2}$ & $1.1 \times 10^{4}$ & $4 \times 10^{3}$ & $3 \times 10^{4}$ & $1.1 \times 10^{4}$ & $4 \times 10^{3}$ & $3 \times 10^{4}$ & $>1.6 \times 10^{5}$ & - & - & $>1.6 \times 10^{5}$ & - & - \\
\hline $\mathbf{A}_{3}$ & 800 & $3 \times 10^{2}$ & $2 \times 10^{3}$ & 140 & $6 \times 10$ & $3.5 \times 10^{2}$ & 300 & $1 \times 10^{2}$ & $1.1 \times 10^{2}$ & 20 & 10 & $1 \times 10^{2}$ \\
\hline $\mathbf{A}_{4}$ & 70 & $2 \times 10$ & $2 \times 10^{2}$ & 230 & $9 \times 10$ & $8.5 \times 10^{2}$ & 330 & $1.5 \times 10^{2}$ & $7.7 \times 10^{2}$ & $<\mathrm{DL}$ & - & - \\
\hline $\mathbf{B}_{2}$ & 20 & 10 & $1 \times 10^{2}$ & 20 & 10 & $1 \times 10^{2}$ & 20 & 10 & $1 \times 10^{2}$ & $<\mathrm{DL}$ & - & - \\
\hline $\mathbf{B}_{4}$ & $<$ DL & - & - & 40 & 10 & $1.5 \times 10^{2}$ & $<\mathrm{DL}$ & - & - & $<\mathrm{DL}$ & - & - \\
\hline $\mathrm{C}_{1}$ & 20 & 10 & $1 \times 10^{2}$ & 40 & 10 & $1.5 \times 10^{2}$ & $>1.6 \times 10^{5}$ & - & - & $<\mathrm{DL}$ & - & - \\
\hline $\mathrm{C}_{2}$ & 20 & 10 & $1 \times 10^{2}$ & 20 & 10 & $1 \times 10^{2}$ & $1.1 \times 10^{3}$ & $4 \times 10^{2}$ & $3 \times 10^{3}$ & 20 & 10 & $1 \times 10^{2}$ \\
\hline $\mathrm{C}_{3}$ & 20 & 10 & $1 \times 10^{2}$ & 20 & 10 & $1 \times 10^{2}$ & 20 & 10 & $1 \times 10^{2}$ & $<\mathrm{DL}$ & - & - \\
\hline $\mathrm{C}_{5}$ & $<$ DL & - & - & 70 & $2 \times 10$ & $2 \times 10^{2}$ & $<$ DL & - & - & $<\mathrm{DL}$ & - & - \\
\hline
\end{tabular}

*: not analyzed; < DL: below detection limit (fecal indicator microorganisms: DL $=20$ ); fecal streptococci: $\mathrm{FS}$, C. perfringens: $\mathrm{CP}$, total coliforms: TC and E. coli: E.C.

Samples $\mathrm{A}_{5}, \mathrm{~A}_{6}, \mathrm{~A}_{7}, \mathrm{~B}_{1}, \mathrm{~B}_{3}, \mathrm{C}_{4}, \mathrm{D}, \mathrm{E}$ and $\mathrm{F}$ presented values below detection limit for all fecal microorganisms analysed (FS, $\mathrm{CP}, \mathrm{TC}$ and $\left.\mathrm{EC}\right)$.

Another point to be considered in this study is that the numbers of fecal bacteria may be underestimated because of the formation of viable but non-culturable cells (VNC) (Davies et al., 1995). It has been reported that simulated solar radiation had a sub-lethal effect on E.coli populations during short $(1 \mathrm{~h})$ exposures, by leading to a loss in culturability and the formation of VNC forms (Muela et al., 2000).

Consequently, the low level or non-detected abundances of microbial indicators, mainly E.coli, at sites $A_{3}$ and $A_{4}$, might be due to the interference of these physical factors. Despite these factors however, fecal indicators were present in great abundance near the outfall sites $\left(A_{1}\right.$ and $\left.A_{2}\right)$, indicating a recent contamination event.

Greater abundances of $C$. perfringens and total coliforms were detected at a distance of $50 \mathrm{~m}$ (sites $A_{1} \rightarrow A_{4}$ ) from Ferraz, with maximum values at the sewage outfall. By comparison, $C$. perfringens from the sewage outfall of McMurdo Station (U.S.A) were found as far as $200 \mathrm{~m}$ from the station (Edwards et al., 1998). C. perfringens and fecal coliforms at the 
Rothera Research Station were not detected at this same distance, but abundances of both microorganisms declined with distance from the outfall. However, C. perfringens abundances did not decline as quickly as fecal coliform abundances (Hughes \& Thompson, 2004). In our study at the Ferraz Station, C. perfringens and total coliforms were found in greater abundances than $E$.coli until to $50 \mathrm{~m}$ from the outfall.

Fecal streptococci were found as far as 150 $\mathrm{m}$ from the outfall of Terra Nova Station (Italy) (Bruni et al., 1997). Maximum abundances of streptococci were found only $50 \mathrm{~m}$ from the outfall of Ferraz Station, the same distance as for the maximum abundances for $C$. perfringens and total coliforms. Compared to fecal streptococci, E.coli were only detected up to $20 \mathrm{~m}$ from the outfall of Ferraz. Total coliforms were found at low levels at about $100 \mathrm{~m}$ from the outfall of the Terra Nova Station, while fecal coliforms and fecal streptococci were absent.

Integration of Chemical and Microbiological Parameters

In general, the analysis of fecal sterols and fecal indicator microorganisms in the sediments from Admiralty Bay indicates that sewage contamination has accumulated to a relatively high level only in the immediate vicinity of the sewage outfall site $\left(\mathrm{A}_{1}\right)$. Figure 2 shows the decrease of these values with distance from the outfall. When the recorded values of fecal indicator microorganisms were below the detection limit $(<20 \mathrm{MPN} / 100 \mathrm{~g}$ dry weight $)$, the detection limit value (20 MPN/100g dry weight) was used in the graphs and calculations.

An assessment of human sewage input at each sampling site may be obtained when the parameters, (1) cop/e-cop ratio, (2) cop/e-cop ratio vs the percentage of cholesterol, (3) the percentage of coprostanols/total sterols and (4) microbiological indicators, collectively, are evaluated. For example, site $A_{1}$ (at the sewage outfall) is a site intensely contaminated by human sewage as shown by the fecal sterol level. The parameters applied along the outfall transect $\left(A_{1} \rightarrow A_{7}\right)$ show that these sites receive some human sewage effluent discharge from Ferraz. However, the levels of sterols and fecal indicator microorganisms are much lower than at $\mathrm{A}_{1}$, probably due to dilution or physical factors affecting the survival of fecal indicator microorganisms.

Microbiological parameters are in agreement with sterol profiles for the sites near the sewage outfall. Sites $A_{1} \rightarrow A_{4}$ indicate that human sewage contamination has recently occurred in this area. However, the fecal microorganism abundances do not indicate a low/moderate human sewage input in sediments at distances $>50 \mathrm{~m}$ from the outfall $\left(\mathrm{A}_{5} \rightarrow\right.$ $\left.A_{7}\right)$. This happens because fecal indicator microorganisms and sterols present different decay and survival rates.

Fecal indicator microorganisms such as E. coli (time for $90 \%$ of the population to die $=25$ to 55 h) and fecal streptococci (time for $90 \%$ of the population to die $=29$ to $122 \mathrm{~h}$ ) (Lessard \& Sieburth, 1983) persist for a short time in marine waters, particularly in the Antarctic environment. The absence of fecal microorganisms far from the sewage outfall may be attributed to the low survival rates.

The fecal sterols present in the sediments represent the concentrations at the time of deposition, because they are insoluble in water and are highly resistant to microbial degradation (Muller et al., 1979). In view of the fact that only the first $3 \mathrm{~cm}$ of surface sediments was analyzed and the sedimentation rate in Admiralty Bay (near the sewage outfall) is $\sim 4.1$ mm.year ${ }^{-1}$ (Figueira et al., unpublished data), the concentration of fecal sterols detected may be associated with the last 7.3 years of sewage input.

Traces of fecal sterols at sites $50 \mathrm{~m}$ from the sewage outfall indicate an accumulated fecal input deposited during the period from 1992 to 1999 , due to the microbiological indicators' not surviving in the environment as long as the fecal sterols.

Fecal microorganisms, mainly $C$. perfringens, may be used to determine sterol sources when high concentrations of fecal sterols are found at remote sites. For example, site $\mathrm{F}(15 \mathrm{~km}$ from the Ferraz Station) showed a high percentage of coprostanols in total sterols that might be associated with human sewage contamination. However, all the microbiological parameters indicated an absence of fecal indicator bacteria and, therefore, these sterols came most probably from marine mammals.

The use of chemical and microbiological indicators provides a method for determining the degree and possible source of fecal pollution in the Antarctic coastal environment.

\section{ACKNOWLEDGEMENTS}

Financial support was obtained from the Antarctic Brazilian Program (PROANTAR) by a grant from the Conselho Nacional de Pesquisa (CNPq) with logistical support from the Secretaria da Comissão Interministerial para os Recursos do Mar (SECIRM). César de Castro Martins, expresses his thanks for the financial support received from a CAPES M.Sc. scholarship. The authors wish to thank the Ferraz Station staff for the collection of samples, Prof. Dr. M. M. de Mahiques IOUSP, for the grain-size analyses, colleagues of the Laboratório de Química Orgânica Marinha and Laboratório de Microbiologia Ambiental, IOUSP, for suggestions and, especially, Dra Satie Taniguchi for her useful comments on this report. 


\section{REFERENCES}

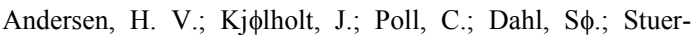
Lauridsen, F.; Pedersen, F. \& Bj申rnestad, E. 1998 Environmental risk assessment of surface water and sediments in Copenhagen harbour. Water Sci. Technol., 37:263-272.

American Public Health Association - APHA. 1995. Standard methods for the examination of water and wastewater. $19^{\text {th }}$ ed., Washington, APHA. 1666p.

Bruni, V.; Maugeri, T. L. \& Monticelli, L. 1997. Fecal pollution indicators in Terra Nova Bay (Ross Sea, Antarctica). Mar. Pollut. Bull., 34:908-912.

Davies, C. M.; Long, J. A. H.; Donald, M. \& Ashbolt, N. J. 1995. Survival of fecal microorganisms in marine and freshwater sediments. Appl. environ. Microbiol., 61:1888-1896

Delille, D. \& Delille, E. 2000. Distribution of enteric bacteria in Antarctic Seawater surrounding the Dumont d'Urville permanent Station (Adelie Land). Mar. Pollut. Bull., 40:869-872.

Edwards, D. D.; McFeters, G. A. \& Venkatesan, M. I. 1998 Distribution of Clostridium perfringens and fecal sterols in a benthic coastal Marine environment influenced by sewage outfall from McMurdo Station, Antarctica. Appl. Environ. Microb., 64:2596-2600.

Freame, B. \& Fitzpatrick, B. W. F. 1972. The use of Differential Reinforced Clostridial Medium for the isolation and enumeration of clostridia. - In "Isolation of anaerobes" edited by Shapton, D. A. \& Board, R. G., Academic Press, London, New York. 48-55.

Figueira, R. C. L.; Martins, C. C.; Montone, R. C. Figueiredo, A. M. G.; Tessler, M. G. \& Mahiques, M. M. ${ }^{210} \mathrm{~Pb},{ }^{226} \mathrm{Ra}$ and ${ }^{137} \mathrm{Cs}$ levels and sedimentation rate in Admiralty Bay, Antarctic Peninsula (unpublished data).

Green, G.; Skerratt, J. H.; Leeming, R. \& Nichols, P. D. 1992. Hydrocarbon and coprostanol levels in seawater, sea-ice algae and sediments near Davis Station in Eastern Antarctica: a regional survey and preliminary results for a field fuel spill experiment. Mar. Pollut. Bull., 25:293302.

Green, G. \& Nichols, P. D. 1995. Hydrocarbons and sterols in marine sediments and soils at Davis Station, Antarctica: a survey for human-derived contaminants. Antarct. Sci. 7:137-144.

Grimalt, J. O.; Fernandez, P.; Bayona, J. M.; \& Albaiges, J. 1990. Assessment of fecal sterols and ketones as indicators of urban sewage inputs to coastal waters. Envir. Sci. \& Tech., 24:357-363.

Hill, R. T.; Straube, W. L.; Palmisano, A. C.; Gibson, S. L. \& Colwell, R. R. 1996. Distribution of sewage indicated by Clostridium perfringens at a deep-water disposal site after cessation of sewage disposal. Appl. Environ. Microb., 62:1741-1746.

Howington, J. P.; McFeters, G. A.; Barry, J. P. \& Smith, J. J. 1992. Distribution of the McMurdo station sewage plume. Mar. Pollut. Bull., 25:324-327.

Hughes, K. A. 2003. Influence of seasonal environmental variables on the distribution of presumptive fecal coliforms around an Antarctic research station. Appl. Environ. Microb., 69:4884-4891.
Hughes, K. A. \& Thompson, A. 2004. Distribution of sewage pollution around a maritime Antarctic research station indicated by fecal coliforms, Clostridium perfringens and fecal sterol markers. Environm. Pollut., 127:315-321

Jeng, W. L. \& Han, B. C. 1994. Sedimentary coprostanol in Kaohsiung Harbor and Tan-Shui Estuary, Taiwan. Mar. Pollut. Bull., 28:494-499.

Kawakami, S. K. \& Montone, R. C. 2002. An efficient ethanol-based analytical protocol to quantify fecal steroids in marine sediments. J. Brazil. Chem. Soc., 13:226-232.

Karentz, E.; Bothwell, M. L.; Coffin, R. B.; Hanson, A.; Herndl, G. J.; Lesser, M. P.; Moeller, R. E.; Morris, D. P.; Neale, P. J.; Sabders, R. W.; Weiler, C. S.; Wetzel, R. G. 1994. Impact of UV-radiation on pelagic freshwater ecosystems: report of working group on bacteria and phytoplankton. Arch. Hydrobiol. Beih., 43:31-69.

Leeming, R. \& Nichols, P. D. 1996. Concentrations of coprostanol that correspond to existing bacterial indicator guideline limits. Water Res., 30:2997-3006.

Lessard, E. J. \& Sieburth, J. M. 1983. Survival of natural sewage populations of enteric bacteria in diffusion and batch chambers in the marine environment. Appl. Environ. Microbiol., 45:950-959

Lipp, E. K.; Farrah, A. S. \& Rose, J. B. 2001. Assessment and impact of microbial fecal pollution and human enteric pathogens in coastal community. Mar. Pollut. Bull., 42:286-293.

Maldonado, C.; Venkatesan, M. I.; Phillips, C. R. \& Bayona, J. M. 2000. Distribution of trialkylamines and coprostanol in San Pedro shelf sediments adjacent to a sewage outfall. Mar. Pollut. Bull., 40:680-687.

Martins, C. C.; Venkatesan, M. I. \& Montone, R. C. 2002. Sterols and Linear alkylbenzenes (LABs) in marine sediments from Admiralty Bay, Antarctica: a regional survey and preliminary results from 97-98 austral summer sampling. Antarct. Sci., 14:244-252.

McFeters, G. A.; Barry, J. P. \& Howington, J. P. 1993. Distribution of enteric bacteria in Antarctic seawater surrounding a sewage outfall. Water Res., 27:645-650.

Mudge, S. M. \& Bebianno, M. J. 1997. Sewage contamination following an accidental spillage in the Ria Formosa, Portugal. Mar. Pollut. Bull., 34:163-170.

Muela, A.; Garcia-Bringas, J. M.; Arana, I. \& Barcina, I. 2000. The effect of simulated solar radiation on Escherichia coli: The relative roles of UV-B; UV-A and photosynthetically Active Radiation. Microb. Ecol., 39:65-71.

Muller, G.; Kanazawa, A. \& Teshima, S. 1979. Sedimentary record of fecal pollution in part of Lake Constance by coprostanol determination. Naturwissenschaften. 66: 520-522.

Nguyen, D.; Bruchet, A. \& Arpino, P. 1995. Determination of sterols in sewage sludge by combined in situ trimethylsilylation/supercritical fluid extraction and CG/MS. Environ. Sci. Technol., 29:1686-1690.

Nichols, P. D. \& Leeming, R. 1991. Tracing sewage in the marine environment. Chem. Austr., 58(7):274-276.

Noble, R. T.; Lee, I. M. \& Schiff, K. C. 2004. Inactivation of indicator micro-organisms from various sources of fecal contamination in seawater and freshwater. J. Appl. Microb., 96:464-472. 
Sherwin, M. R.; Van Vleet, E. S.; Fossato, V. U. \& Dolch, F.

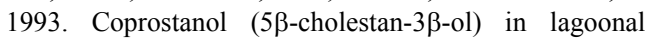
sediments and mussels of Venice, Italy. Mar. Pollut. Bull., 26:501-507.

Skanavis, C. \& Yanko, W. A. 2001. Clostridium perfringens as a potential indicator for the presence of sewage solids in marine sediments. Mar. Pollut. Bull., 42:31-35.

Sorensen, D. L.; Eberl, S. G. \& Dickson, R. A. 1989. Clostridium perfringens as a point source indicator in non-point polluted streams. Water Res., 23:191-197.

Venkatesan, M. I. \& Santiago, C. A. 1989. Sterols in oceans sediments: novel tracers to examine habitats of cetaceans, pinnipeds, penguins and humans. Mar. Biol. 102:431-437.
Venkatesan, M. I. \& Kaplan, I. R. 1990. Sedimentary coprostanol as an index of sewage addition in Santa Monica basin, southern California. Environ. Sci. Technol., 24:208-214.

Venkatesan, M. I. \& Mirsadeghi, F. H. 1992. Coprostanol as sewage tracer in McMurdo Sound, Antarctica. Mar. Pollut. Bull., 25:328-333.

(Manuscript received 23 June 2004: revised 10 November 2004; accepted 18 February 2005) 